\title{
LINC-PINT Gene
}

National Cancer Institute

\section{Source}

National Cancer Institute. LINC-PINT Gene. NCI Thesaurus. Code C118124.

This gene is involved in signaling pathway regulation. 